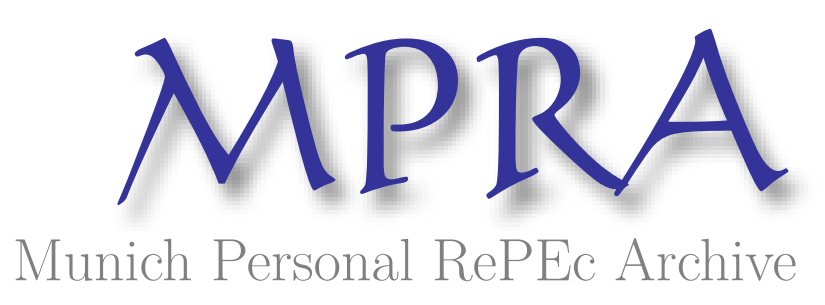

\title{
Role of Education in Economic Growth in the Russian Federation and Ukraine
}

Osipian, Ararat

Vanderbilt University

1 January 2007

Online at https://mpra.ub.uni-muenchen.de/7590/

MPRA Paper No. 7590, posted 10 Mar 2008 01:17 UTC 
Vanderbilt University

\title{
Role of Education in Economic Growth
}

\author{
in the Russian Federation and Ukraine
}

\author{
Ararat L. Osipian* \\ ararat.osipian@vanderbilt.edu \\ araratos@yahoo.com \\ Dept. of Leadership, Policy, and Organizations \\ Vanderbilt University \\ Peabody \#514 \\ 230 Appleton Place \\ Nashville, TN 37203-5721 \\ Ph: (615)322-8000 \\ Fax: (615)3432391
}

Nashville, TN - 2007

\footnotetext{
* Ararat L. Osipian is a Ph.D. candidate in the Department of Leadership, Policy and Organizations at Peabody College of Education at Vanderbilt University, USA
} 
This study analyses the role and impact of education on economic growth in the two largest economies of the former Soviet Bloc, namely, the Russian Federation and Ukraine. It attempts to estimate the significance of different educational levels, including secondary and tertiary education, for initiating substantial economic growth that now takes place in these two countries. This study estimates the model of endogenous economic growth and the system of linear and log-linear equations that account for different time lags in the possible impact of higher education on economic growth. The model estimation shows that there is no significant impact of educational attainment on economic growth. The results from the system of equations indicate that an increase in access of population to higher education brings positive results for the per capita GDP growth in the long term. Increasing the number of college-educated specialists leads to sustainable economic growth. The suggestion can be made that the ground for the 20002007 rapid economic growth in Ukraine and in the Russian Federation was laid down in early 1990s. This contradicts commonly accepted perception about the crisis decade of 1990s in the former Soviet Bloc.

Key words: economic growth, education, Russia, Ukraine 


\section{Introduction}

The ideas of public spending and foreign investment as the major engines for potential growth, especially in developing nations, are now replaced with the ideas about the importance of reinvestment and development of domestic markets. The theories of growth based on the fundamental assumption that a significant influx of the resources is necessary to initiate sustainable growth do not hold. They might work to a certain degree in the developing world, but appear to be insufficient to explain rapid economic growth in the Russian Federation, Ukraine, and other countries of the former Soviet Bloc.

Despite the difficulties and local crises, the socio-economic transition in the Russian Federation and Ukraine may be considered as successful. Political and economic reforms lead to the creation of predominantly market economy. By 2004, the Russian Federation and Ukraine achieved pre-transition level of GDP per capita. The positive economic growth takes place in both national economies since 1999. One of the engines of such growth may be high educational level of the workforce and an increasing access to tertiary education.

This study analyses the role and impact of human capital on per capita economic growth in transition economies in the Russian Federation and Ukraine and uses Hungary and Poland for comparison. The factors that are associated with the human capital in terms of education levels are analyzed in order to measure this impact. Our approach is to estimate the significance of educational levels for initiating substantial economic growth. The model tests empirically the hypothesis that human capital has a positive impact on per capita economic growth in transition economies. We also estimate a system of linear and log-linear equations that account for different time lags in the possible impact of human capital on economic growth. 


\section{Poverty trap}

The poverty trap theory anticipates a large external influx of resources done in a short period of time as the only way to make a national economy caught in low productivity low income situation to move forward and stabilize at a higher level of GDP. A sufficiently large donation would place the economy on a path that leads eventually to a high level of the steady state or possibly to endogenous steady-state growth. Thus, a relatively large quantity of foreign aid might allow an escape from the poverty trap. The poverty trap approach effectively deprived countries of the former Soviet Bloc of the bright economic future. The recent data on rapid economic growth in the Russian Federation and Ukraine point to the opposite.

Leontief (1958) emphasized the role of savings in economic growth: "Among the many factors which determine the growth or stagnation - as the case may be - of a national economy, its rate of saving out of current income and the subsequent increase in income resulting from the investment of these savings play an important role." (Leontief, 1958) The key point here is that preferences of a given national economy between present and future levels of consumption in terms of a conventional set of social indifference curves affect growth. Of course, the problem of maximizing utility - by planning the allocation of income between consumption and investment - over long intervals of time is certainly of considerable interest itself, despite the fact that it was first brought up by Frank Ramsey 70 years ago.

In the study of linear programming, Dorfman, Samuelson, and Solow (1958) analyze, among other things, efficient programs of capital accumulation on the assumption of Leontieftype (fixed coefficient) technologies. Except for the fact that their model of capital accumulation permits nonzero consumption, its characteristics are basically the same as those defining the situation with savings presented by Leontief. 
Dornbush (1996) expanded the growth equation to include these insights on savings and growth. Domestic saving and current account deficit are determinants of growth through capital investment:

$$
Y=Q+\alpha n+r(S+\lambda)
$$

where $S$ is the national saving rate, $\lambda$ is no interest current account deficit expressed as a fraction of GDP, $r$ is the marginal return on capital formation, $n$ is labor. This equation highlights the role of domestic savings. Higher saving rates $(S)$ finance capital accumulation and growth. However, the equation makes the important point that the immediate impact of saving on growth is minor. Assume that the return to capital is 10 percent. Raising the saving rate by 5 percentage points of GDP will then raise the growth rate of output by only 0.5 percentage points. Of course, the compound growth effects of an extra 0.5 percent growth are considerable, but only in the long run.

Carlberg (1997) examined the effects of savings, labor, and the interest rate on international economic growth and obtained the following results: "An increase in the saving rate does affect neither capital per head nor output per head. It reduces foreign debt per head. And it improves consumption per head. An increase in the rate of labor growth leaves no impact on capital per head and output per head. It increases foreign debt per head and worsens consumption per head. An increase in foreign interest rate depresses both capital per head and output per head. Besides, it brings down foreign debt per head. As long as the foreign interest rate is low, the shock deteriorates consumption per head. But as soon as the foreign interest rate is sufficiently high, the shock improves consumption per head." (Carlberg, 1997, p. 5)

Some of the most recent studies that consider impact of foreign financial aid on economic growth are by Boon (1996), Lensink and Morrissey (1999), Barro and Sala-I-Martin (1999), 
Burnside and Dollar (2000), and Hansen and Tarp (2001). The authors examine the interaction between foreign financial assistance and growth. During the recent decades unilateral and multilateral donors provide a substantial amount of financial assistance to the developing countries. The stated goals of this aid are often formulated as poverty alleviation and promotion of economic growth. The results of such projects are not satisfactory in many cases. This necessitates further research of the issue.

Beginning in the 1980 s economists began to conceptualize technological changes from within production. Emphasis was placed on $R \& D$, and the problem of the accumulation of capital was transferred into the problem of investment and the balance between saving and consumption. Labor was an input that could be developed by investing in human capital, and growth was stimulated by improvements in labor quality. The quality of labor was considered as accumulated capital, and firms faced new choices among physical capital and human capital investments.

Valdes (1999) points out that "Ever since the new wave of research on growth theory began in the late 1980s, proponents of the two theories have been (on and off) arguing over which of the two approaches is better. One (possibly the first) round of the dispute was fought in the empirical arena. To meet the empirical finding that $\lambda=-0.022,(\alpha)$ the parameter in the aggregate production function $Y_{t}=K_{t}^{\alpha}\left(A_{t} L_{t}\right)^{1-\alpha}$ has to be approximately to 0.7 (consequently, $1-\alpha=0.3)$. Another round in the debate between the two theories seems to have been constructed over their (as-of-today-known) implications for economic policy." (Valdes, 1999, pp. 168-169) 


\section{The Endogenous Model of Economic Growth}

For deeper investigation of the potential sources of economic growth in the Russian Federation and Ukraine, we choose an endogenous model of economic growth, because the exogenous models of Solow-Swan and Leontief do not adequately describe the transition experience. The debate on whether the accumulation of human capital contributes positively towards raising per capita income growth has reemerged along with the renewed emphasis on the determinants of long-term economic growth.

An endogenous model of economic growth appears to be the most appropriate for our evaluation. First, such model may be applied for cross sectional analysis, which is probably the best way to analyze economic growth in the countries in transition. Second, the model shows the influence and importance of human capital relative to other key inputs on economic growth and to differences across countries. Kalaitzidakis et al. (2001) note that, while both intuition and several theories of endogenous growth point towards a positive effect of human capital on economic growth, empirical evidence on this issue has been mixed (Kalaitzidakis et al., 2001). The purpose of the study is to provide a systematic investigation of the human capital--economic growth nexus. The impact of human capital on economic growth is incorporated according to the Mankiw et al. (1992) framework.

Mankiw et al. assume a production function of the form given below:

$$
Y=K_{t}^{\alpha}-H_{t}^{\beta}\left(A_{t} L_{t}\right)^{1-\alpha-\beta}
$$

where $Y, K, H$, and $L$ represent total output, physical capital stock, human capital stock, and labor, respectively. $A$ is a technological parameter. Technology is assumed to grow exponentially at the rate $\phi$. 
Kalaitzidakis et al. model is in some sense a continuation of the Durlauf and Johnson (1995) work but extends their work in one significant direction. Durlauf and Johnson focus on identifying homogenous subgroups of countries, and they assume that the contribution of human capital to economic growth is the same for all countries within each subgroup. Kalaitzidakis et al. allow the effect of human capital to differ both across countries and also across time. A variety of measures of human capital frequently used in applied growth studies is employed.

The unrestricted growth model may be estimated as follows:

$$
y_{i t}=a_{0}+a_{1} D_{t}+a_{2} D_{j}+a_{3} \ln S_{i t}^{k}+a_{4} \ln \left(n_{i t}+\alpha+\delta+\gamma\right)+a_{5} \ln X_{i t}+a_{6} \ln h_{i t}+\varepsilon_{i t}, \text { (3) }
$$

where $y_{i t}$ refers to the growth rate of income per capita during each period, $S^{k}$ is the share of output devoted to physical capital accumulation, $n_{i t}$ is the rate of growth of the labor force, $\alpha$ is the rate of technical exogenous progress that is constant for all countries in all periods, $\delta$ is the depreciation rate of human capital, $\gamma$ is the depreciation rate of physical capital, $X_{i t}$ is per capita income at the beginning of each period, $h_{i t}$ is human capital measured either as a stock or as a flow. $D_{t}$ and $D_{j}$ are dummy variables for each period and country, i.e. Hungary, Poland, the Russian Federation, and Ukraine, respectively.

The model considers a wide variety of measures of education capital; health and other forms of human capital are not measured. The first measure of education human capital presented by the authors is mean years of schooling for the whole population. This measure is used most frequently in the modern literature on growth. They also examine educational attainment of males and females at the primary, secondary, and post-secondary or tertiary levels. They include educational achievement at the secondary and tertiary level for a number of reasons: “(i) a number of countries have very low or zero values for educational achievement at the tertiary level; (ii) to limit the number of measures of human capital; and (iii) the theoretical 
mechanisms that link human capital of different educational levels to economic growth draw a distinction between basic education (primary) and education that enables the diffusion of ideas (post primary). Finally, for the purposes of comparison with the early literature on human capital, we consider enrollment rates both at the primary and secondary level and by gender." (Kalaitzidakis et al., 2001, p. 234) Human capital in the model is expressed in terms of education only. The rate of depreciation of human capital can be interpreted as a function of healthcare expenditures. It is not an objective of the model to suggest whether the rate of human capital depreciation is linearly related to healthcare expenditures, but the model assumes that higher per capita health care expenditures lead to lower rates of human capital depreciation.

\section{Access to higher education in the FSU}

Number of students in higher education institutions per 10000 population is chosen to analyze access of population to higher education. This indicator reflects level or stock of human capital in the countries as well as dynamics of production of human capital during the significant periods of time. Number of students in higher education institutions per 10000 population in the FSU for the period of 1980-1999 is presented in Table 1.

Contrary to the beliefs about the crisis situation in the Russian Federation and Ukraine, statistics point to the continuous growth in the number of students in higher education institutions per 10000 population. While during the independence and start of the market reforms in 1991 this indicator in Ukraine was equal to 168, by the year 1999 number of students enrolled in higher education institutions per 10000 population has reached 259. This indicator is slightly lower than in the Russian Federation, where number of students per 10000 thousand population grew from 186 in 1991 to 280 in 1999. 
Table 1

Number of students in higher education institutions per 10000 population in the FSU, 1980-1989

\begin{tabular}{|c|c|c|c|c|c|c|c|c|c|c|}
\hline Country & 1980 & 1981 & 1982 & 1983 & 1984 & 1985 & 1986 & 1987 & 1988 & 1989 \\
\hline Azerbaijan & 172 & 172 & 172 & 169 & 163 & 158 & 155 & 149 & 140 & 140 \\
\hline Armenia & 189 & 188 & 189 & 183 & 173 & 163 & 160 & 161 & 168 & 186 \\
\hline Belarus & 183 & 183 & 185 & 185 & 186 & 181 & 179 & 177 & 175 & 185 \\
\hline Georgia & 168 & 170 & 172 & 172 & 169 & 167 & 160 & 160 & 157 & 171 \\
\hline Kazakhstan & 173 & 176 & 179 & 181 & 180 & 172 & 170 & 168 & 167 & 171 \\
\hline Kyrgyzstan & 151 & 154 & 154 & 151 & 148 & 144 & 142 & 136 & 133 & 136 \\
\hline Moldova & 127 & 129 & 130 & 128 & 128 & 126 & 123 & 121 & 122 & 127 \\
\hline Russia & 219 & 219 & 218 & 216 & 213 & 206 & 200 & 194 & 190 & 193 \\
\hline Tajikistan & 142 & 138 & 137 & 133 & 131 & 119 & 115 & 114 & 115 & 125 \\
\hline Turkmenistan & 124 & 125 & 127 & 126 & 122 & 119 & 117 & 117 & 112 & 116 \\
\hline Uzbekistan & 172 & 172 & 170 & 165 & 162 & 155 & 154 & 155 & 155 & 163 \\
\hline Ukraine & 176 & 175 & 175 & 174 & 173 & 167 & 166 & 166 & 165 & 171 \\
\hline Country & 1990 & 1991 & 1992 & 1993 & 1994 & 1995 & 1996 & 1997 & 1998 & 1999 \\
\hline Azerbaijan & 146 & 147 & 134 & 125 & 117 & 128 & 132 & 127 & 134 & 147 \\
\hline Armenia & 191 & 181 & 156 & 124 & 97 & 97 & 142 & 149 & 157 & 160 \\
\hline Belarus & 184 & 180 & 179 & 169 & 181 & 191 & 203 & 219 & 239 & 258 \\
\hline Georgia & 190 & 188 & 167 & 168 & 251 & 231 & 239 & 234 & 236 & 248 \\
\hline Kazakhstan & 171 & 170 & 165 & 163 & 165 & 165 & 176 & 188 & 206 & 245 \\
\hline Kyrgyzstan & 133 & 129 & 119 & 117 & 129 & 142 & 169 & 210 & 274 & 325 \\
\hline Moldova & 125 & 120 & 109 & 108 & 114 & 149 & 159 & 180 & 199 & 212 \\
\hline Russia & 190 & 186 & 177 & 171 & 171 & 188 & 201 & 221 & 245 & 280 \\
\hline Tajikistan & 128 & 124 & 127 & 121 & 127 & 126 & 127 & 126 & 123 & 130 \\
\hline Turkmenistan & 113 & 104 & 96 & 90 & 86 & 70 & 62 & $\ldots$ & $\ldots$ & $\ldots$ \\
\hline Uzbekistan & 165 & 159 & 146 & 123 & 102 & 84 & 71 & 66 & 65 & 68 \\
\hline Ukraine & 170 & 168 & 164 & 159 & 172 & 180 & 192 & 220 & 242 & 259 \\
\hline
\end{tabular}

Source: Commonwealth of Independent States (CIS) - Official Statistics, retrieved from the database in August 8, 2006.

Data for the Russian Federation and Ukraine indicate that during the transition total number of students in higher education institutions per every ten thousand of population was increasing consistently since 1993 despite the decline in some other economic indicators. This proves not only the fact of the continuous positive developments in national systems of higher education based on the market reforms, but also shows continuous growth in accumulation and concentration of human capital in national economies. 
Positive trends in the development of higher education industry and increasing access of population to higher education characterize such countries as Ukraine, the Russian Federation, and Belarus, but are not necessarily characteristics of all the former soviet republics. For instance, in Azerbaijan number of students in higher education institutions per every ten thousand of population as an indicator of access to higher education was declining till 1995 and reached level of 1991 only in 1999, comprising 147 students. This indicator is almost twice lower than in the Russian Federation and Ukraine. In Armenia value of this indicator declined from 191 in 1990 to 97 in 1995 and then increased to 160 in 1999.

In some other former republics situation with access to higher education did not regain its positions of 1991. Indicator of number of students in higher education institutions per every ten thousand of population declined in Uzbekistan from 170 in 1990 to 68 in 1999, and in Turkmenistan—from 113 in 1990 to 62 in 1996. This statistics should always be correlated with demographic and migratory processes in the NIS. One should also account for students receiving their education in other countries, predominantly in other member countries of the NIS.

The data indicate that despite the economic difficulties during the transition period, number of students in higher education institutions per every ten thousand of population was increasing consistently since 1993. This confirms not only continuous and consistent development of the education industry, but also stable increase in the total volume and concentration of human capital in the country.

\section{Data and descriptive statistics}

The data used in the empirical study are selected macroeconomic indicators for Hungary, Poland, the Russian Federation, and Ukraine and cover the period of 1989-2010. Trajectories of 
the indicators overtime taken as $\operatorname{logs}$ are presented in Figures 1, 2, 3, and 4. GDP per capita growth, gross fixed investment annual change, gross national savings rate (percent), and recorded unemployment (percent), for Hungary, Poland, the Russian Federation, and Ukraine for the period of 1989-2010 are presented in Tables 2-5.

Table 2

Real GDP growth per head (percent per annum) in Hungary, Poland, the Russian Federation and Ukraine, 1989-2010

\begin{tabular}{ccccc}
\hline Year & Hungary & Poland & Russia & Ukraine \\
\hline 1989 & 0.999 & - & - & - \\
1990 & -2.893 & -11.900 & - & -4.241 \\
1991 & -11.831 & -7.200 & -5.267 & -8.954 \\
1992 & -2.914 & 2.400 & -14.586 & -10.225 \\
1993 & -0.387 & 3.600 & -8.669 & -13.985 \\
1994 & 3.110 & 5.100 & -12.659 & -22.322 \\
1995 & 1.654 & 7.001 & -4.065 & -11.522 \\
1996 & 1.539 & 6.198 & -3.460 & -9.217 \\
1997 & 4.863 & 7.124 & 1.457 & -2.240 \\
1998 & 5.204 & 5.061 & -5.139 & -1.124 \\
1999 & 4.546 & 4.616 & 6.730 & 0.597 \\
2000 & 6.371 & 4.305 & 10.478 & 6.806 \\
2001 & 4.619 & 1.210 & 5.613 & 11.001 \\
2002 & 4.086 & 1.455 & 5.242 & 6.198 \\
2003 & 3.645 & 3.869 & 7.757 & 10.398 \\
2004 & 5.484 & 5.360 & 7.611 & 3.371 \\
2005 & 4.400 & 3.447 & 6.823 & 6.100 \\
2006 & 4.200 & 5.100 & 6.700 & 6.400 \\
2007 & 3.800 & 4.800 & 6.100 & 6.500 \\
2008 & 4.000 & 4.400 & 5.400 & 6.700 \\
2009 & 4.200 & 4.100 & 4.900 & 6.300 \\
2010 & 4.200 & 4.100 & 4.600 & $4.969 t 12$ \\
\hline
\end{tabular}

Source: Economist Intelligence Unit. Retrieved from the database in August 12, 2006. Composed based on EIU calculations, US Census Bureau, Ministry of Economy and European Integration, Hungarian Central Statistical Office, State Committee of Statistics, RosStat, Poland Quarterly Statistics, Statistical Yearbook, UN, IMF, International Financial Statistics. 
Dynamics of the GDP per capita growth for Hungary, Poland, the Russian Federation, and Ukraine for the period of 1989-2010 that accounts for the log trajectories are presented in Figure 1.

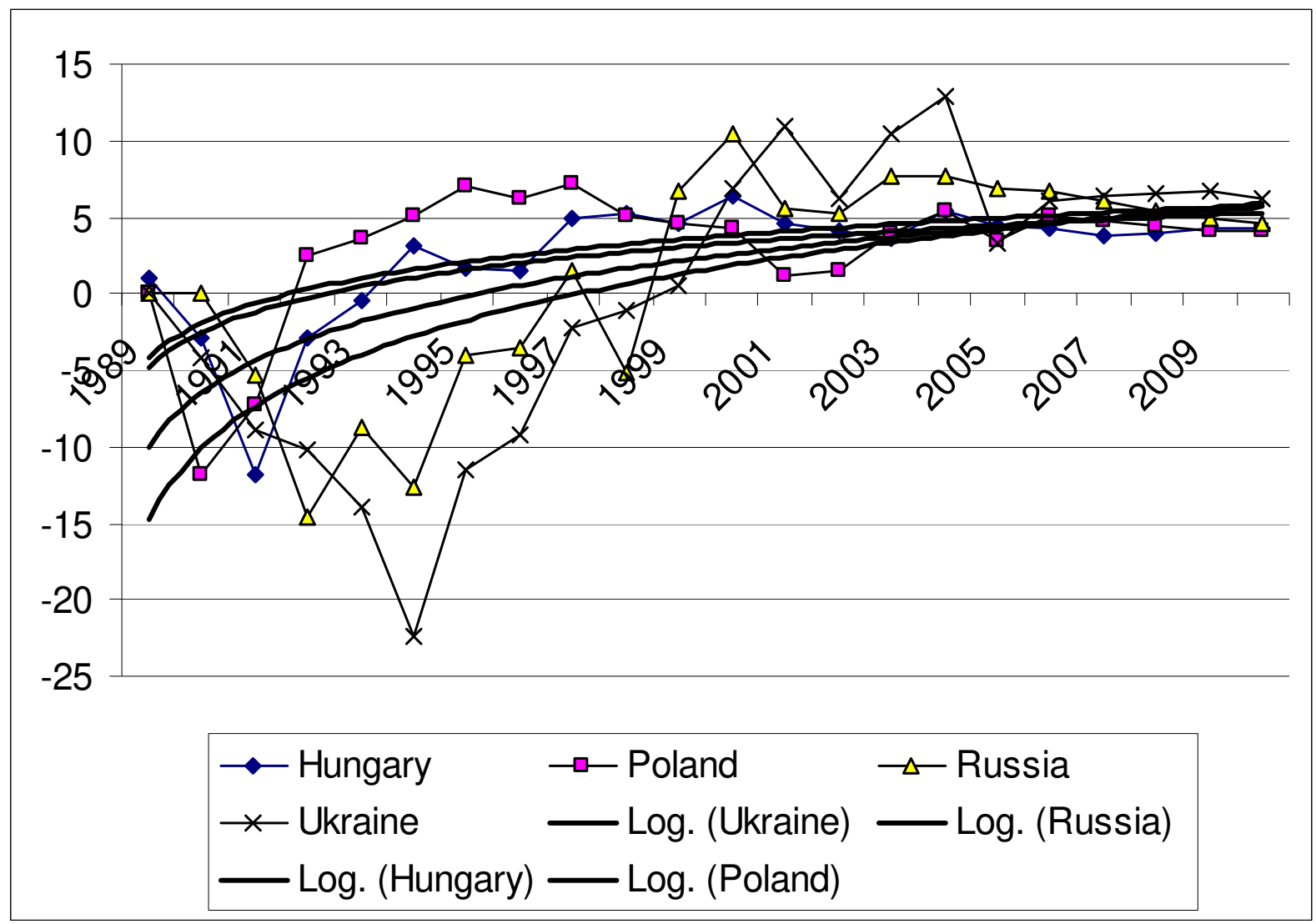

Figure 1. Real GDP per capita growth in Hungary, Poland, the Russian Federation, and Ukraine (with the log trajectories), 1989-2010

As shown in Figure 1, GDP per capita growth in Hungary, Poland, the Russian Federation, and Ukraine was in the different initial position in each country. The convergence of the GDP per capita growth rate in these countries occurs during the period of 1989-2010. 
Table 3

Gross fixed investment (percent real change per annum) in Hungary, Poland, the Russian Federation, and Ukraine, 1989-2010

\begin{tabular}{ccccc}
\hline Year & Hungary & Poland & Russia & Ukraine \\
\hline 1989 & 6.990 & -2.145 & - & - \\
1990 & -7.136 & -9.776 & - & - \\
1991 & -10.427 & -4.404 & -15.600 & -13.030 \\
1992 & -2.639 & 2.326 & -41.500 & -34.626 \\
1993 & 2.031 & 2.900 & -25.800 & -50.263 \\
1994 & 12.470 & 9.201 & -26.000 & -9.960 \\
1995 & -6.753 & 16.500 & -15.267 & -20.036 \\
1996 & 6.747 & 19.700 & -21.200 & 3.636 \\
1997 & 9.158 & 21.800 & -7.900 & 4.316 \\
1998 & 13.234 & 14.000 & -12.400 & 0.720 \\
1999 & 5.893 & 6.600 & 6.400 & 12.650 \\
2000 & 7.665 & 2.700 & 18.100 & 9.350 \\
2001 & 5.929 & -9.700 & 10.200 & 3.400 \\
2002 & 9.294 & -6.300 & 2.800 & 15.800 \\
2003 & 2.450 & -0.100 & 12.800 & 20.500 \\
2004 & 8.400 & 6.400 & 11.290 & -0.300 \\
2005 & 6.558 & 6.500 & 10.499 & 5.000 \\
2006 & 5.500 & 8.000 & 10.200 & 9.000 \\
2007 & 5.200 & 8.000 & 11.000 & 10.000 \\
2008 & 5.000 & 7.000 & 10.600 & 7.500 \\
2009 & 5.500 & 7.000 & 10.900 & 8.500 \\
2010 & 6.000 & 7.000 & 10.000 & 12.2006. \\
\hline
\end{tabular}

Source: Economist Intelligence Unit. Retrieved from the database in August 12, 2006. Composed based on EIU calculations, US Census Bureau, Ministry of Economy and European Integration, Hungarian Central Statistical Office, State Committee of Statistics, RosStat, Poland Quarterly Statistics, Statistical Yearbook, UN, IMF, International Financial Statistics.

Dynamics of the gross fixed investment annual change for Hungary, Poland, the Russian Federation, and Ukraine for the period of 1989-2010 that accounts for the log trajectories are presented in Figure 2. 


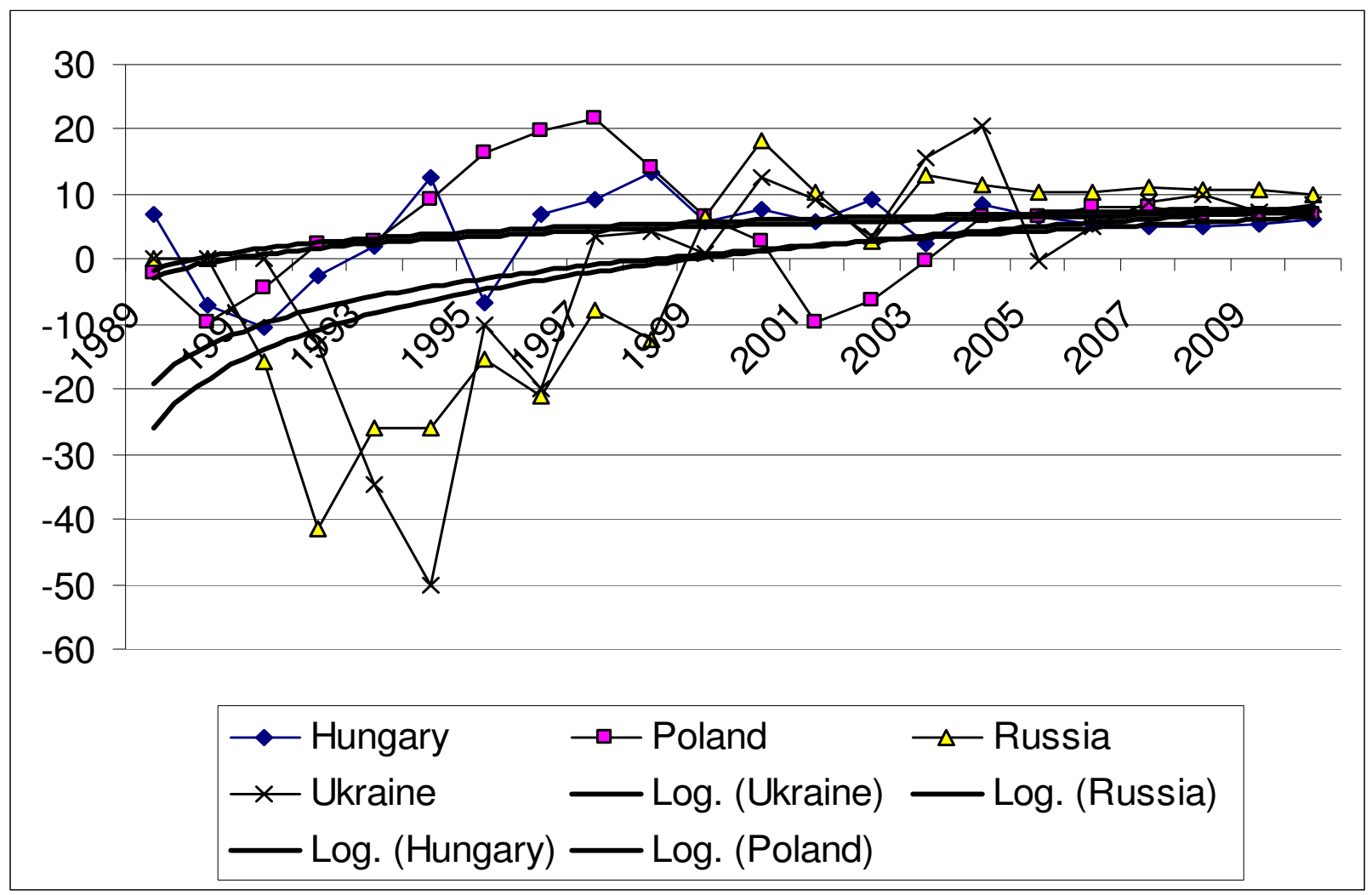

Figure 2. Investment in constant capital in Hungary, Poland, the Russian Federation, and Ukraine (with the log trajectories), 1989-2010

As shown in Figure 2, levels of the gross fixed investment in Hungary, Poland, the Russian Federation, and Ukraine were in the different initial positions in each country. However, gross fixed investment rates converge. The convergence of the gross fixed investment rates in these countries occurs during the period of 1989-2010. Gross fixed investment rates in Poland and Hungary were higher than in the Russian Federation and Ukraine. The process of convergence of the growth gross fixed investment rate coincides with the convergence of the GDP per capita growth in these countries that occurs during the period of 1989-2010. This confirms significant and positive effect of the investment on growth. 
Table 4

Gross national savings rate (percent) in Hungary, Poland, the Russian Federation, and Ukraine, 1989-2010

\begin{tabular}{lcccc}
\hline Year & Hungary & Poland & Russia & Ukraine \\
\hline 1989 & 26.971 & 44.082 & - & - \\
1990 & 26.537 & 30.219 & - & - \\
1991 & 21.662 & 17.380 & - & - \\
1992 & 17.021 & 12.030 & - & - \\
1993 & 8.910 & 10.237 & 31.334 & 32.659 \\
1994 & 12.427 & 14.014 & 28.358 & 23.675 \\
1995 & 18.908 & 19.307 & 27.662 & 20.037 \\
1996 & 21.591 & 18.772 & 26.434 & 18.759 \\
1997 & 22.022 & 19.753 & 21.957 & 17.667 \\
1998 & 21.644 & 21.030 & 15.044 & 22.729 \\
1999 & 20.867 & 17.786 & 27.393 & 24.494 \\
2000 & 21.378 & 19.003 & 36.729 & 27.482 \\
2001 & 20.308 & 17.937 & 32.972 & 27.800 \\
2002 & 17.877 & 16.087 & 28.502 & 31.800 \\
2003 & 15.739 & 16.642 & 29.010 & 25.200 \\
2004 & 16.787 & 15.931 & 30.997 & 20.000 \\
2005 & 16.384 & 17.629 & 31.833 & 19.600 \\
2006 & 17.600 & 18.600 & 31.400 & 19.500 \\
2007 & 18.400 & 19.100 & 30.200 & 19.600 \\
2008 & 18.000 & 19.500 & 27.400 & 21.700 \\
2009 & 18.300 & 19.800 & 26.100 & 26.300 \\
2010 & 19.100 & 19.700 & & \\
\hline
\end{tabular}

Source: Economist Intelligence Unit. Retrieved from the database in August 12, 2006. Composed based on EIU calculations, US Census Bureau, Ministry of Economy and European Integration, Hungarian Central Statistical Office, State Committee of Statistics RosStat, Poland Quarterly Statistics, Statistical Yearbook, UN, IMF, International Financial Statistics.

Dynamics of the savings rate annual change for Hungary, Poland, the Russian Federation, and Ukraine for the period of 1989-2010 that accounts for the log trajectories are presented in Figure 3. 


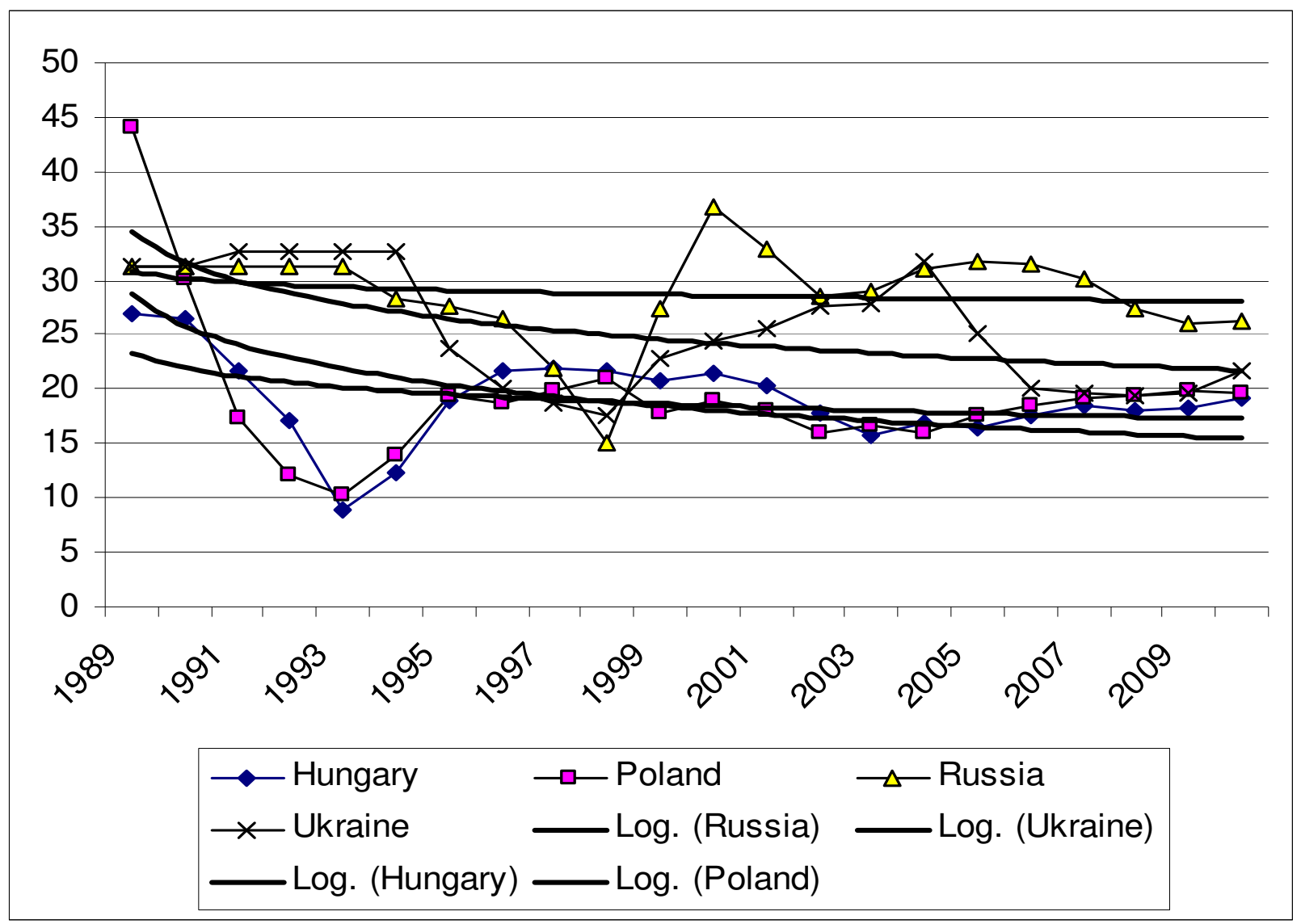

Figure 3. Savings rate in Hungary, Poland, the Russian Federation, and Ukraine (with the $\log$ trajectories), 1989-2010

As shown in the Figure 3, levels of the savings rate in Hungary, Poland, the Russian Federation, and Ukraine have not changed significantly during the period of 1989-2010. Sharp decline of the savings rate in the Russian Federation and Ukraine in 1999 can possibly be explained by the world financial crisis of 1997-1998. 
Table 5

Recorded unemployment (percent) in Hungary, Poland, the Russian Federation, and Ukraine, 1989-2010

\begin{tabular}{ccccc}
\hline Year & Hungary & Poland & Russia & Ukraine \\
\hline 1989 & & & & - \\
1990 & - & 3.433 & - & - \\
1991 & - & 8.975 & - & - \\
1992 & 9.941 & 12.925 & - & - \\
1993 & 12.098 & 14.992 & - & - \\
1994 & 10.982 & 16.492 & - & - \\
1995 & 10.432 & 15.208 & 7.017 & - \\
1996 & 10.109 & 14.292 & 8.300 & 2.300 \\
1997 & 8.912 & 11.492 & 9.258 & 3.700 \\
1998 & 7.926 & 9.975 & 10.808 & 4.200 \\
1999 & 7.057 & 11.992 & 11.875 & 4.100 \\
2000 & 6.440 & 14.008 & 12.617 & 3.600 \\
2001 & 5.765 & 18.000 & 10.492 & 3.700 \\
2002 & 5.870 & 19.700 & 9.033 & 3.500 \\
2003 & 5.932 & 19.900 & 8.133 & 3.500 \\
2004 & 6.084 & 19.600 & 8.625 & 3.100 \\
2005 & 7.278 & 18.200 & 8.175 & 3.500 \\
2006 & 7.200 & 16.900 & 7.583 & 3.800 \\
2007 & 7.700 & 16.000 & 7.000 & 4.100 \\
2008 & 7.400 & 15.200 & 6.600 & 4.400 \\
2009 & 6.800 & 14.600 & 6.400 & 4.800 \\
2010 & 6.400 & 13.700 & 6.300 & 6.100 \\
\hline
\end{tabular}

Source: Economist Intelligence Unit. Retrieved from the database in August 12, 2006. Composed based on EIU calculations, US Census Bureau, Ministry of Economy and European Integration, Hungarian Central Statistical Office, State Committee of Statistics RosStat, Poland Quarterly Statistics, Statistical Yearbook, UN, IMF, International Financial Statistics.

Dynamics of the official rate of unemployment annual change for Hungary, Poland, the Russian Federation, and Ukraine for the period of 1989-2010 that accounts for the $\log$ trajectories are presented in Figure 4. As shown in Figure 4, levels of the official unemployment rate in Hungary, Poland, the Russian Federation, and Ukraine have risen dramatically in early 1990s and have stabilized later. Such a sharp increase in unemployment may be explained in part by the absence of the official unemployment in the USSR and Eastern Europe. Relatively low 
level of the registered unemployment in the Russian Federation and Ukraine in 1990s should be considered critically as it appears to be much lower than the real unemployment rate.

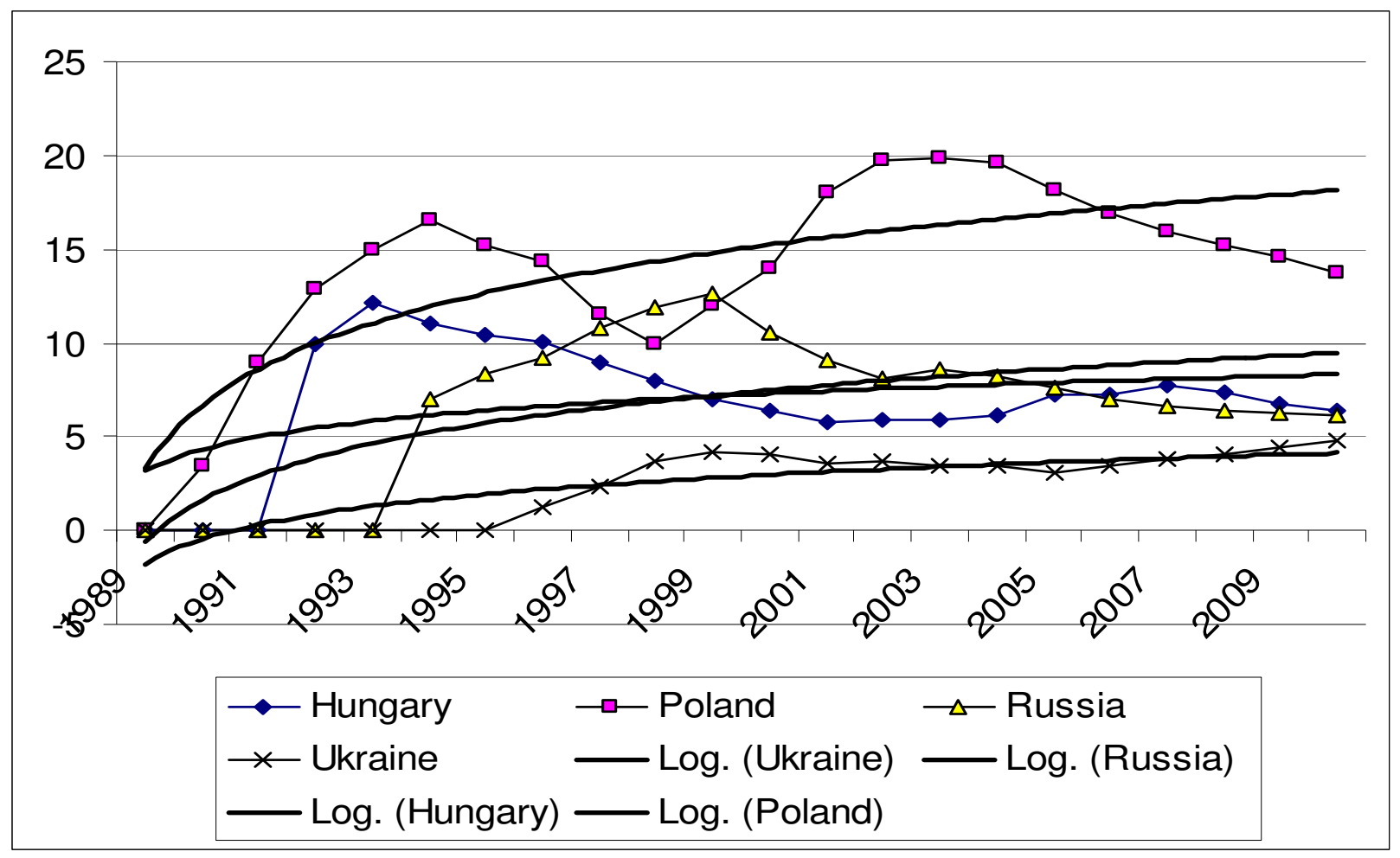

Figure 4. Registered level of unemployment in Hungary, Poland, the Russian Federation, and Ukraine (with the log trajectories), 1989-2010

\section{Empirical results}

This section details the findings from the estimation of the model. The empirical results are summarized in Table 6. Unlike Kalaitzidakis et al., we include savings as a percent of GDP instead of the share of output devoted to physical capital accumulation, (the ratio of investment to GDP). The model is estimated using Pooled Least Squares for the growth equation. First, we present results for the model including the share of workers with completed secondary education in the total labor force as our measure of human capital. The regression results for Hungary, Poland, and Russia are presented in Table 6, column (1). 
Table 6

Regression results for Hungary, Poland, and the Russian Federation

\begin{tabular}{|c|c|c|c|c|}
\hline \multicolumn{5}{|c|}{$\begin{array}{l}\text { Dependent Variable: GNP per capita growth } \\
\text { Method: Pooled Least Squares }\end{array}$} \\
\hline Variable & (1) & (2) & (3) & (4) \\
\hline $\log$ (GDP) & -2.281950 & -4.130292 & -3.049124 & -1.898404 \\
\hline $\log (n+a+d e l t a)$ & 211.7075 & 284.1125 & 324.8825 & 468.8184 \\
\hline $\log ($ GNIPC $)$ & 3.372103 & 10.60201 & 8.409283 & 21.52700 \\
\hline $\log (\operatorname{Sec} E d)$ & -2.432554 & - & - & - \\
\hline $\log (\operatorname{Ed} 15)$ & - & -92.03441 & -87.10878 & - \\
\hline $\log (\mathrm{Ed} 25)$ & - & - & - & 0.586599 \\
\hline Y1993 & - & - & 1.150828 & - \\
\hline Y1997 & - & - & 1.323753 & - \\
\hline HungaryY1993 & - & - & - & 5.921217 \\
\hline PolandY1993 & - & - & - & 7.003009 \\
\hline RussiaY1993 & - & - & - & -6.587396 \\
\hline HungaryY1997 & - & - & - & 0.435318 \\
\hline PolandY1997 & - & - & - & -6.885087 \\
\hline RussiaY1997 & - & - & - & 1.095112 \\
\hline \multicolumn{5}{|l|}{ Fixed Effects } \\
\hline Hungary & -30.12454 & -90.42709 & -118.2021 & -534.4805 \\
\hline Poland & -25.88381 & -76.90207 & -105.8910 & -522.5860 \\
\hline Russia & -33.83000 & -78.51058 & -107.8946 & -525.3103 \\
\hline Ukraine & - & -69.59642 & -100.5148 & - \\
\hline R-squared & 0.883036 & 0.868996 & 0.874926 & 0.933623 \\
\hline Adjusted R-squared & 0.824554 & 0.815053 & 0.799882 & 0.800869 \\
\hline S.E. of regression & 3.040127 & 3.001439 & 3.122116 & 3.238834 \\
\hline Log likelihood & -43.72036 & -58.12998 & -44.66185 & -23.35189 \\
\hline Durbin-Watson stat & 2.735736 & 2.437320 & 2.459151 & 3.042483 \\
\hline Mean dependent var & -0.062002 & -0.827354 & -0.827354 & -0.062002 \\
\hline S.D. dependent var & 7.258046 & 6.979211 & 6.979211 & 7.258046 \\
\hline Sum squared resid & 110.9085 & 153.1468 & 146.2141 & 62.94029 \\
\hline F-statistic & 30.19851 & 37.58905 & 20.98589 & 9.376994 \\
\hline Prob(F-statistic) & 0.000007 & 0.000000 & 0.000003 & 0.006563 \\
\hline
\end{tabular}

The coefficient for the logarithm of the sum of the rate of growth of the labor force, the rate of technical exogenous progress, and the depreciation rate for human and physical capital is positive and statistically significant at the five percent level of significance. The rate of growth of the labor force is presented as growth of employment only. The rate of technical exogenous progress that is constant for all countries is taken as $\alpha=1$. The depreciation rate for human and physical capital is taken as $\delta=0.1$. 
Average years of schooling per person 15 years old and older is the measure of human capital in the GDP per capita growth model for Hungary, Poland, Russia, and Ukraine presented in Table 6, column (2). The regression with the average years of schooling per person 25 years old and older as the measure of human capital gives similar results. We include two dummy variables in the model to test for shifts in growth over time. Year 1993 is equal to years one for the 1993 and earlier and is equal to 0 for other years. Year 1997 is equal to one for the years 1997 and later and is equal to 0 for other years.

We estimate the impact of average years of schooling per person 15 years old and older as the measure of human capital on the GDP per capita growth in the regression model for Hungary, Poland, Russia, and Ukraine. The results are presented in column (3). The coefficient of average years of schooling per person 15 years old and older measure of human capital is negative and insignificant at the five percent level of significance. Coefficients for both dummy variables are insignificant at the five percent level of significance. This indicates that there is no significant difference for these countries between the periods of time before 1993, from 1993 till 1997, and after 1997 in the GDP per capita growth model.

Regression results for Hungary, Poland, Russia, and Ukraine using the share of workers with completed secondary education in the total labor force as our measure of human capital are presented in column (4). In addition, we test interaction of the countries' fixed effects with the time variables. The coefficient for the share of workers with completed secondary education in the total labor force is negative and insignificant at the five percent level of significance. Coefficients for both dummy variables are insignificant at the five percent level of significance. This indicates that there is no significant difference for each country between the periods of time before 1993, from 1993 till 1997, and after 1997 in the GDP per capita growth model. 
Regressions with average years of schooling per person 25 years old and older measure of human capital give similar results.

The empirical results are supportive of the predictions from the original growth models (Kalaitzidakis et al., 2001): an increase in human capital does not correlate with per capita economic growth in countries with a high level of human capital. Regressions using average number of schooling years per person 25 years old and older or the average number of schooling years per person 15 years old and older as the human capital measure demonstrate a positive correlation in Poland but a negative correlation in Hungary, even though Hungary has the most sustainable GNP per capita growth.

Coefficients for total savings as a share of GDP in the regressions indicate a negative but insignificant effect on GNP per capita growth. It confirms our prediction that savings of the population are not invested in production and cannot be considered as share of output devoted to physical capital accumulation. This reflects the problem of underinvestment in production in Russia and Ukraine in particular.

Gross national income per capita has a positive and significant effect on per capita GNP growth. An increase in income per capita leads to a higher level of growth. This contrasts to the convergence hypothesis presented in the reviewed literature. The empirical model did not examine threshold levels of human capital, but the growth experience of a country may well differ according to which side of the threshold of human capital it is on. This should be examined in the future.

The results of the estimation of the system of linear and log-linear equations that account for changes in investment, savings, unemployment, education, and medical services are presented below. The independent variables were dropped consequently and the time lags were 
taken as five-, six-, seven-, and ten-year time lags. Selected results are presented in Tables 7 to 9. We comment only on the coefficients with 5 percent level of significance. Regression results of GDP per capita growth to investment, savings, unemployment, education and healthcare for the Russian Federation and Ukraine for the period of 1990-2010 with the constant coefficient (1) and without the constant coefficient (2) are presented in Table 7. Indicators of the level of access to higher education and medical services are taken with the five year time lag. 
Table 7

Regression results of GDP growth to investment, savings, unemployment, education, and healthcare for the Russian Federation and Ukraine with the 5-year time lag, 1990-2010

\begin{tabular}{|c|c|c|c|c|c|c|c|c|}
\hline \multirow{3}{*}{$\begin{array}{l}\text { Country } \\
\text { Estimation method } \\
\text { Independent variable }\end{array}$} & \multicolumn{2}{|c|}{ Russian Federation } & \multicolumn{2}{|c|}{ Ukraine } & \multicolumn{2}{|c|}{ Russian Federation } & \multicolumn{2}{|c|}{ Ukraine } \\
\hline & (1) & (2) & (1) & (2) & (3) & (4) & (3) & (4) \\
\hline & OLS & OLS & OLS & OLS & OLS & OLS & OLS & OLS \\
\hline \multirow[t]{3}{*}{ Investment } & $0.544219 * *$ & $0.349321 * * *$ & $0.341820 * *$ & $0.384583 * *$ & $0.430864 * *$ & $0.448183 * *$ & $0.416201 * *$ & $0.516480 * *$ \\
\hline & $(0.151921)$ & $(0.088695)$ & $(0.153252)$ & $(0.142531)$ & $(0.042274)$ & $(0.052814)$ & $(0.042274)$ & $(0.105189)$ \\
\hline & [3.582251] & [3.938462] & [2.230438] & [2.698245] & [10.19206] & [8.486119] & [3.862983] & [4.910021] \\
\hline \multirow[t]{3}{*}{ Savings } & -0.038764 & 0.226039 & 0.901649 & 1.196193 & 0.133635 & 0.015774 & 0.200090 & 0.394320 \\
\hline & $(0.260842)$ & $(0.213105)$ & $(0.728499)$ & $(0.637364)$ & $(0.128833)$ & $(0.151186)$ & $(0.128833)$ & $(0.488916)$ \\
\hline & {$[-0.148611]$} & [1.060695] & [1.237682] & {$[1.876784]$} & [1.037277] & {$[0.104332]$} & {$[0.453996]$} & {$[0.806520]$} \\
\hline \multirow[t]{3}{*}{ Unemployment } & -1.156294 & 1.021889 & 0.410878 & 0.130104 & & & & \\
\hline & $(1.554713)$ & $(0.645762)$ & $(1.675531)$ & $(1.609592)$ & -- & -- & -- & -- \\
\hline & {$[-0.743735]$} & {$[1.582455]$} & [0.245223] & {$[0.080831]$} & & & & \\
\hline \multirow[t]{3}{*}{ Education } & -0.014755 & 0.041590 & -0.066783 & -0.060944 & 0.017864 & -0.001487 & -0.040690 & 0.021822 \\
\hline & $(0.050371)$ & $(0.037368)$ & $(0.089199)$ & $(0.086963)$ & $(0.022262)$ & $(0.026335)$ & $(0.022262)$ & $(0.083934)$ \\
\hline & {$[-0.292917]$} & [1.112996] & {$[-0.748699]$} & {$[-0.700799]$} & {$[0.802457]$} & {$[-0.056456]$} & {$[-0.500659]$} & [0.259988] \\
\hline \multirow[t]{3}{*}{ Healthcare } & -2.180633 & -0.474601 & 2.500816 & -0.346361 & -1.484476 & 0.053926 & 5.761747 & -0.298297 \\
\hline & $(1.176011)$ & $(0.366858)$ & $(3.148024)$ & $(0.212904)$ & $(0.645769)$ & $(0.143247)$ & $(0.645769)$ & $(0.186454)$ \\
\hline & {$[-1.854263]$} & {$[-1.293691]$} & [0.794408] & {$[-1.626842]$} & {$[0.05510]$} & {$[0.376454]$} & [1.692321] & {$[-1.599844]$} \\
\hline R-squared & 0.959353 & 0.941654 & 0.954202 & 0.941654 & 0.961679 & 0.929628 & 0.950381 & 0.924120 \\
\hline Adjusted R-squared & 0.918707 & 0.883307 & 0.877871 & 0.883307 & 0.939781 & 0.903239 & 0.917301 & 0.891600 \\
\hline Mean dependent var & 1.778636 & 1.778636 & 3.925778 & 3.925778 & 0.908000 & 0.908000 & 0.135273 & 0.135273 \\
\hline S.D. dependent var & 7.173865 & 7.173865 & 7.361281 & 7.361281 & 7.475416 & 7.475416 & 10.968320 & 10.968320 \\
\hline
\end{tabular}

Notes: each column is a separate regression of the growth rate on investment, savings, unemployment, education, and healthcare.

(1), (3) with constant coefficient.

(2) and (4) without constant coefficient.

Other variables defined as follows: investment, savings, unemployment, education healthcare.

Standard errors are reported in parentheses. t-statistics are reported in square brackets.

Asterisk *** indicates statistical significance at the 1-percent level, ** at the 5-percent level, and * at the 10-percent level. 
Table 8

Regression results of GDP growth to investment, savings, and education in the Russian Federation and Ukraine, 1990-2010

\begin{tabular}{|c|c|c|c|c|c|c|}
\hline \multirow[t]{2}{*}{ Country } & \multicolumn{3}{|c|}{ Russian Federation } & \multicolumn{3}{|c|}{ Ukraine } \\
\hline & $(1)$ & $(2)$ & $(3)$ & (4) & $(5)$ & $(6)$ \\
\hline $\begin{array}{l}\text { Estimation method } \\
\text { Independent variable }\end{array}$ & OLS & OLS & OLS & OLS & OLS & OLS \\
\hline \multirow{3}{*}{ Investment } & 0.449635 & 1.704101 & 1.461792 & 0.513473 & 2.141293 & 3.389514 \\
\hline & $(0.041511)$ & $(0.927185)$ & $(0.708749)$ & $(0.054756)$ & $(0.698971)$ & $(1.035916)$ \\
\hline & [10.83167] & [2.905393] & {$[2.062496]$} & [9.377552] & [3.063492] & [3.271996] \\
\hline \multirow[t]{3}{*}{ Savings } & -0.014491 & 4.149711 & 6.209534 & 0.384124 & 19.06934 & 6.853271 \\
\hline & $(0.124123)$ & $(5.092608)$ & $(1.937277)$ & $(0.204437)$ & $(3.728733)$ & $(3.637917)$ \\
\hline & [-0.116749] & [0.814850] & {$[3.205291]$} & [1.878933] & [5.114161] & [1.883845] \\
\hline \multirow[t]{3}{*}{ Education } & -0.004167 & -4.512862 & -3.356831 & 0.042449 & 11.31633 & -4.170212 \\
\hline & $(0.019454)$ & $(2.905393)$ & $(1.194651)$ & $(0.030395)$ & $(4.021590)$ & $(2.113641)$ \\
\hline & {$[-0.214207]$} & {$[-1.553271]$} & [-2.809885] & [1.396600] & [2.813894] & [-1.972999] \\
\hline R-squared & 0.937675 & 0.683352 & 0.674533 & 0.922595 & 0.893438 & 0.673608 \\
\hline Adjusted R-sq. & 0.918978 & 0.547646 & 0.593166 & 0.896794 & 0.853477 & 0.601077 \\
\hline Mean dep. var & 1.744214 & 6.668545 & 6.668545 & 0.843000 & 5.854083 & 5.854083 \\
\hline S.D. dep. var & 7.197464 & 1.575530 & 1.575530 & 10.175860 & 4.683886 & 4.683886 \\
\hline
\end{tabular}

time lag. In columns $2,3,5$ and 6 education is taken at a 10-year time lag. All the independent variables are taken as logs. 1,2,4,5 are with constant coefficient, 3 and 6 are without constant coefficient.

Standard errors are reported in parentheses. t-statistics are reported in square brackets.

Asterisk *** indicates statistical significance at the 1-percent level, ** at the 5-percent level, and * at the 10-percent level 
Regression results indicate positive effects of investments on the GDP per capita growth rate. An increase in investment leads to an increase in per capita GDP growth in all the countries. Other variables are not statistically significant. Effects of the variables that represent access of population to higher education and medical services are within the limits of statistical error. This statement holds when indicators of the level of access to higher education and medical services are taken with the five, six, and seven year time lags.

Positive effects of investment in fixed capital in the Russian Federation and Ukraine are higher than in Poland and Hungary. One percent increase in investments in the Russian Federation and Ukraine leads to an increase of the per capita GDP within the limits of 0.37 to 0.55 percent. While in Poland and Hungary this indicator stays within the limits of 0.22 to 0.37 percent.

The dependency between the per capita GDP growth and the independent variables we use in the regressions may be nonlinear. We test system of log-linear equations, where all independent variables are taken as logarithms. Initially, we estimate an equation that includes logarithms of all independent variables, including investment, savings, unemployment, education, and health. Then variables of unemployment and health are consequently taken out from the equations. Indicators of the level of access of population to higher education and medical services are taken consequently with the five, six, seven, and ten year time lags for all the equations. All combinations of log-linear equations are estimated with and without the constant coefficient.

Regression results indicate positive effects of an increase in investment on the per capita GDP growth in the Russian Federation and Ukraine. Investment coefficients are positive and statistically significant in all of the equations with the goodness of fit within the limits of 0.8 to 
0.95. Regression results of per capita GDP growth to logarithms of investment, savings, and education with the constant coefficient in the Russian Federation and Ukraine for the period of 1990-2010 indicate positive effect of an increase in investment in fixed capital, savings, and access to education on the per capita GDP growth. All coefficients of the independent variables are statistically significant. Indicators of the level of access of population to higher education are taken with the ten year time lag.

Regression results of GDP per capita growth to investment, savings, and education for the Russian Federation and Ukraine for the period of 1990-2010 with the constant coefficient (1) and without the constant coefficient (2) are presented in Table 9. Indicators of the level of access to higher education are taken with the ten year time lag.

Table 9

Regression results of GDP growth to investment, savings, and education in Ukraine, 1990-2010

\begin{tabular}{lccc} 
Country & Russian Federation & \multicolumn{2}{c}{ Ukraine } \\
Estimation method & $(2)$ & $(1)$ & $(2)$ \\
Independent variable & OLS & OLS & OLS \\
\hline Investment & $1.461792^{* * * *}$ & $2.141293^{* *}$ & $3.389514^{*}$ \\
& $(0.708749)$ & $(0.698971)$ & $(1.035916)$ \\
Savings & {$[2.062496]$} & {$[3.063492]$} & {$[3.271996]$} \\
& $6.209534^{* *}$ & $19.06934^{*}$ & $6.853271^{* * *}$ \\
Education & $(1.937277)$ & $(3.728733)$ & $(3.637917)$ \\
& {$[3.205291]$} & {$[5.114161]$} & {$[1.883845]$} \\
& $-3.356831^{* *}$ & $11.31633^{* *}$ & $-4.170212^{* * *}$ \\
R-squared & $(1.194651)$ & $(4.021590)$ & {$[2.113641)$} \\
Adjusted R-squared & {$[-2.809885]$} & {$[2.813894]$} & \\
Mean dependent var & & & \\
S.D. dependent var & 0.674533 & 0.893438 & 0.673608 \\
& 0.593166 & 0.853477 & 0.601077 \\
& 6.668545 & 5.854083 & 5.854083 \\
& 1.575530 & 4.683886 & 4.683886
\end{tabular}

Notes: each column is a separate regression of the growth rate on investment, savings, and education. Standard errors are reported in parentheses. t-statistics are reported in square brackets.

Asterisk * indicates statistical significance at the 1-percent level, ** at the 5-percent level, and *** at the 10-percent level. 
Estimation of the equations that consider indicators of access to higher education and medical services with the seven year time lag does not bring statistically significant results. This supports our suggestion that an increase in access of population to higher education does not bring positive results for the per capita GDP growth in the short term. Moreover, enrollment in a higher education institution equates to temporary withdrawal from the work force. Both the level of unemployment and the opportunity costs of obtaining education are of certain concern here. However, an increase in access of population to higher education brings positive results for the per capita GDP growth in the long term. Increasing number of college-educated specialists leads to sustainable economic growth. Apparently, background for the 2000-2005 rapid economic growth in Ukraine and in the Russian Federation was laid down in early 1990s. This contradicts commonly accepted perception about the crisis decade of 1990s.

Estimation of the system of equations where all the variables-dependent and independent—were presented in the form of logarithms confirms positive effect of an increase in investment and per capita GDP growth. For instance, one percent increase in investment in fixed capital in Ukraine leads to 0.639 percent increase in per capita GDP growth. Results of the Vector Autoregression Estimates (VAR) and Impulse Response Function indicate generally positive effects of investment on per capita GDP growth in the short run. In the long run a most significant positive influence of investment in fixed capital on per capita GDP growth occurs during the first two years and then diminishes.

\section{Conclusion}

As follows from the regression results, investments in fixed capital have positive effect on the GDP per capita growth rate. Contribution of investments to the GDP per capita growth in 
the Russian Federation is more significant than in Hungary and Poland. Positive effect of investment on per capita GDP growth in Ukraine is more significant than that in the Russian Federation, Poland, and Hungary. The results support theoretical statement that in transition and post-transition economies savings are not analogous to investments. This means that savings are not necessarily invested in the national economy at full scale. Process of reinvestment is weak. This finding makes obvious underdevelopment of the national stock markets and proves necessity for further development of the capital market, including institutional reform and strengthening of the national banking sector.

Regression results of per capita GDP growth to logarithms of investment, savings, and education with the constant coefficient in the Russian Federation and Ukraine for the period of 1990-2010 indicate positive effect of an increase in investment in fixed capital, savings, and access to education on the per capita GDP growth when indicators of the level of access of population to higher education are taken with the ten year time lag.

An increase in access of population to higher education brings positive results for the per capita GDP growth in the long term. Increasing number of college-educated specialists leads to sustainable economic growth. Apparently, background for the 2000-2005 rapid economic growth in Ukraine and in the Russian Federation was laid down in early 1990s. This contradicts commonly accepted perception about the crisis decade of 1990s.

Results of the Vector Autoregression Estimates (VAR) and Impulse Response Function indicate generally positive effects of investment on per capita GDP growth in the short run. In the long run a most significant positive influence of investment in fixed capital on per capita GDP growth occurs during the first two years and then diminishes. The regression results present strong empirical evidence in support of continuing investment in fixed capital in order to sustain 
economic growth. Investments in fixed capital are backed by the growing education quality of the work force.

The impact of human capital accumulation on economic growth remains controversial. In different research, conclusions reached depend on the definition of human capital, the methodology used and the time period and set of countries over which the model is estimated. Our objective in this research is to present a study of the link between human capital accumulation and GDP per capita growth in countries in transition, making use of a consistent data set and alternative definitions of human capital. As anticipated, parametric estimates reveal no link between the two variables: for different measures of human capital, there is no significant growth effect.

The empirical results are supportive of the predictions from the original growth models (Kalaitzidakis et al., 2001): increase in human capital does not correlate with per capita economic growth in countries with a high level of human capital. We also show that there is no significant difference in the basic growth model over time. These trend effects did not differ across countries. Overall, our results do not offer any policy direction for this small set of transition economies. However, we want to emphasize the fact that high level of human capital in Hungary, Poland, Russia, and Ukraine needs to be reproduced on a constant scale. Also, the process of accumulation of human capital will have a positive impact on GDP per capita growth in the long run.

Substantial GDP per capita growth in Hungary and Poland in the late 1990s may well be explained by the success in economic restructuring and institutional reform. The slow initial process of restructuring and institutional changes in Russia and Ukraine led to a low level of GDP per capita growth. Nevertheless, positive changes in the economy and the society overall, 
are the result of the structural changes in the economy, institutional reforms, development of the market type of behavior among population, development of market infrastructure, improved management, regional diversification, stabilization of the national currency, slowdown in both "brain drain" and capital outflow, and high level of human capital that was a ground for economic growth.

The educational level of population in the former Soviet Union was higher than in Poland and Hungary. Educational attainment in the Russian Federation and Ukraine was among the highest in the world for decades, being on par and sometimes even higher than in such developed Western democracies as France, Switzerland, and the United Kingdom and way above educational level of population in such developing countries as Brazil and China. The next advancement will become possible based on the process of renovation and investment into principal capital. From this perspective we suggest further institutional and structural changes in the economies. It will increase domestic and foreign investment, further develop domestic market, and sustain already achieved substantial GDP per capita growth.

\section{References}

Barro, R. (1997). Determinants of Economic Growth: A Cross-Country Empirical Study. New York: Cambridge University Press.

Barro, R. (2000). Inequality and Growth in a Panel of Countries. Journal of Economic Growth, 1, pp. 5-32.

Barro, R., \& Lee, J. (1996). International Measures of Schooling Years and Schooling Quality. American Economic Review, 86, pp. 218-223.

Barro, R., \& Sala-i-Martin, X. (1999). Economic Growth. Boston: The MIT Press. 
Boon, P. (1996). Politics and the Effectiveness of Foreign Aid. European Economic Review, 40(2), pp. 289-329.

Burnside, C., \& Dollar, D. (2000). Aid, Policies and Growth. American Economic Review, 90, pp. 847-867.

Carlberg, M. (1997). International Economic Growth. Berlin: Phisica-Verlag.

Dorfman, R., Samuelson, P., \& Solow, R. (1958). Linear Programming and Economic Analysis. New York: Penguin.

Dornbush, R. (1996). Stabilization, Debt, and Reform. Policy Analysis for Developing Countries. London: Prentice Hall.

Hansen H., \& Tarp, F. (2001). Aid and Growth Regression. Journal of Development Economics, 64(2), p. 547-570.

Kalaitzidakis, P., Mamuneas, T., Savvides, A., \& Stengos, T. (2001). Measures of Human Capital and Nonlinearities in Economic Growth. Journal of Economic Growth, 3, pp. 229-254.

Lensink, R., \& Kuper, G. (2000). Recent Advances in Economic Growth: a Policy Perspective. In M. S. Oosterbaan, Thijs de Ruyter van Steveninck, and N. van der Windt (Eds.). The Determinants of Economic Growth. New York: Kluwer Academic Publisher, 2000.

Lensink, R., \& Morrissey, O. (1999). Aid Instability as a Measure of Uncertainty and the Positive Impact of Aid on Growth. CREDIT Research Paper 99/6, University of Nottingham.

Leontief, W. (1938). The Significance of Marxian Economics for Present-day Economic Theory. American Economic Review. 
Leontief, W. (1958). Theoretical Note of Time-Preference, Productivity of Capital, Stagnation, and Economic Growth. American Economic Review, 1.

Leontief, W. (1966). Essays in Economics: Theories and Theorizing. Oxford: Oxford University Press.

Mankiw, G., Romer, D., \& Weil, D. (1992). A Contribution to the Empirics of Economic Growth. The Quarterly Journal of Economics, 2, pp. 407-437.

Valdes, B. (1999). Economic Growth: Theory, Empirics, and Policy. Northampton: Edward Elgar Publishing. 